\title{
Individual Lower Limb Orthosis
}

\author{
Jozef Živčák ${ }^{1}$, Viktória Rajtúková ${ }^{2}$, Viktória Krajňáková ${ }^{3 *}$, Radovan Hudák ${ }^{4}$ and Daniela \\ Kátlovská ${ }^{5}$
}

1 Dr. h. c. mult. prof. Ing. Jozef Živčák, PhD., MPH, Technical University of Košice, Faculty of Mechanical Engineering, Department of Biomedical Engineering and Measurement, Letná 9, 04200 Košice

2 Ing.Viktória Rajtúková, PhD., Technical University of Košice, Faculty of Mechanical Engineering, Department of Biomedical Engineering and Measurement, Letná 9, 04200 Košice

3 Viktória Krajñáková, Technical University of Košice, Faculty of Mechanical Engineering, Department of Biomedical Engineering and Measurement, Letná 9, 04200 Košice

4 Radovan Hudák, Technical University of Košice, Faculty of Mechanical Engineering, Department of Biomedical Engineering and Measurement, Letná 9, 04200 Košice

5 Daniela Kátlovská, Slovak University of Technology in Bratislava, Faculty of Mechanical Engineering, Námestie Slobody 17 812 31, Bratislava 1

\begin{abstract}
The aim of the study was to design an individual lower limb protés for a patient who suffered serious injuries in the ankle area. The orthos have a therapeutic, prophylactic, but also rehabilitative effect, and their main task is to protect and stabilize the musculoskeletal system. Attention is focused on the design of the model of the orthas using Autodesk - Meshmixer. The proposed orton contributes to improving the patient's life not only physically, but also mentally. Important aspects of the correctly chosen model of the orthes are knowledge of the patient's medical history, requirements and level of workload. The subjectivity of the assessment of the oreson model may be considered a restriction.
\end{abstract}

Keywords: Additive manufacture, Plastic, Individual orthosis, Meshimixer, Injury, 3D print

\section{Introduction}

Thanks to the evolving technology in the field of medicine, it is possible to mitigate the consequences of injuries. The production of prosthetic and orthotic aids for humans, which are produced using modern additive technologies, is gaining more and more prominence. Their advantage is the use of a wide range of materials, shortening production time and allow the production of individual devices for patients with special needs. Individually manufactured devices are intended to improve the patient's life after an injury and ensure a quick return to everyday work and social life. This work describes the design and manufacture of an orthosis using digitization methods. [1]

\section{Experimental Section}

All necessary patient information was obtained using an Artec Eva 3D scanner. [9] [12] They were processed and ready for further use, so the STL format, which is compatible with the Meshmixer program, was used. Alternatives to patient orthoses have been proposed in this program. [13]

The patient established the following requirements: functionality in the field, longer endurance when walking, lightening of the foot, reduction of foot pressure, foot support, foot fixation, soft padding and insole.

\section{Procedure for designing the first type of orthosis}

The design of the type of orthosis was a reflection of the design provided to the patient. The orthosis is designed to encircle the limb below the knee joint, which should ensure the stability of the entire lower limb. [2] Joints were placed on both sides of the orthosis, i.e. in the place where the ankle joint is located, in order to ensure dorsal 
and plantar flexion. The goal of the orthosis is dorsal and plantar flexion in the ankle and simplification of walking. On the prepared cleansing model, the contour of the orthosis was modeled using the function. [3]

After modelling the orthesis, the outer part was subsequently modelled. To fill the space that arose in the orthesis as a result of the patient defect, a pelota was formed, which was also used to fill the defect inside the orthes. [4] [5]

The section, which was used from the outside, was then pulled into the space and inserted into the defect and the pelota, which was used as a filler from the inside, was further adjusted to elastic. [6]
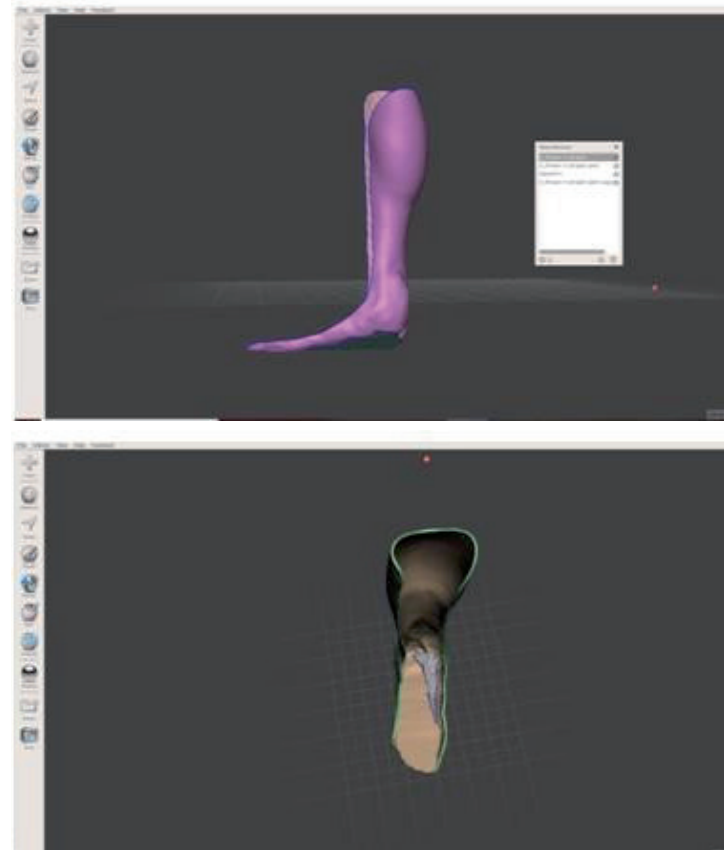

Figure 1: Filling the defect from the outside and inside.

The thickness of the orthosis was increased by $4 \mathrm{~mm}$ using Select $\rightarrow$ Edit $\rightarrow$ Extrude.

After adjusting the orthosis from, a joint was formed. A suitable site on the orthosis was chosen to create the joint. A sphere was placed at the selected location and adjusted to the desired size using Edit $\rightarrow$ Dimension. [7] [8]

In this way, an articulated head was created to which the handle was modeled. The base for the articulated head, which was pulled into the space and on which the extension was modeled, was used to create the articulated well. The procedure was then repeated on the other side of the orthosis.

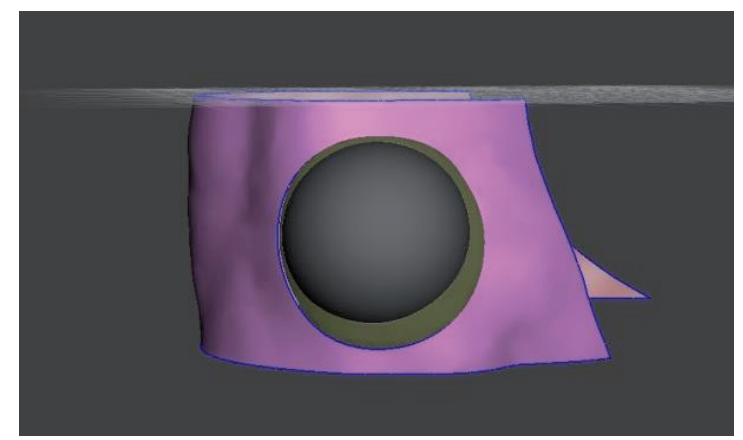

Figure 2: Joint formation.
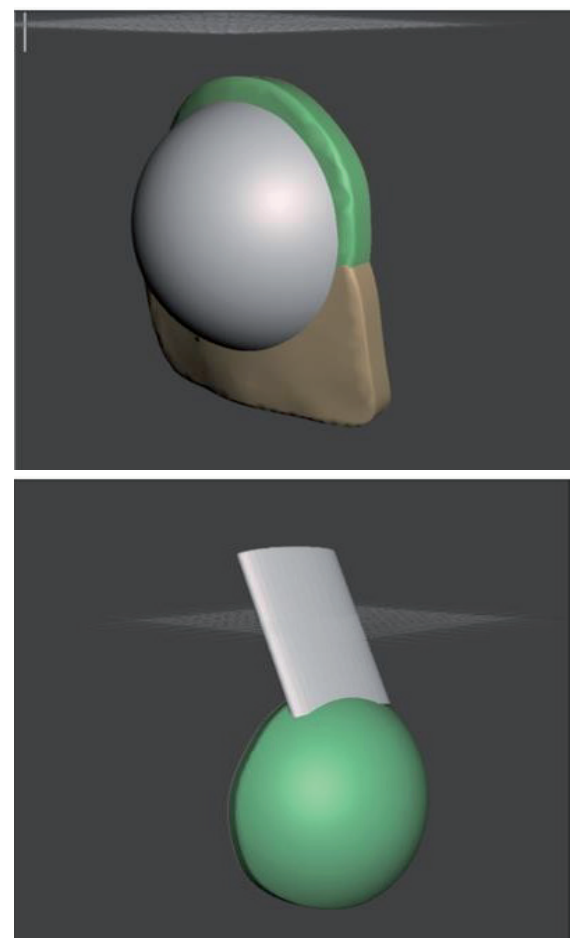

Figure 3: Articulated head and hole.

The orthosis was divided into two parts - the calf part and the foot. Articulated pits were placed on the calf part and articulated heads on the foot, and holes were made to place velcro, which were created by selecting an object from the side panel and then using the Edit $\rightarrow$ Transform function to adjust the size and location. [10]

The last step was to create a porous structure to prevent excessive sweating in the calf area. Several functions were used - Select $\rightarrow$ BrushMode, which was used to mark the place where the porous structure will be located. [11]

Subsequently, Select $\rightarrow$ Remesh function was used, where the pore density was set and the pore 
size was adjusted using the Edit $\rightarrow$ Make pattern function.

After the completion of the porous structure, we created the final appearance of the orthosis, which is shown in the picture. [14]

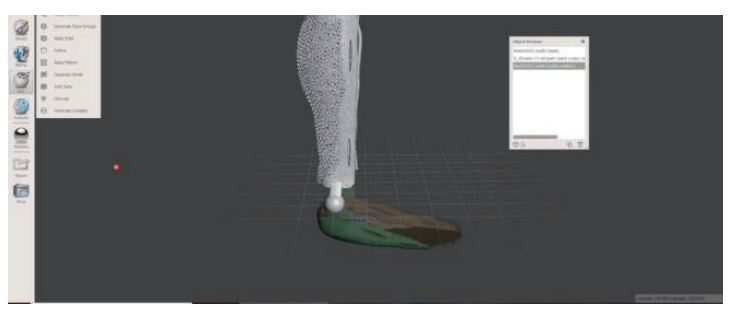

Figure 4: Final orthosis.

\section{Results and Discussion}

The patient had the main and final word in the design of the orthosis. One of the most important criteria for evaluation is the total area, which should provide support to the affected limb and thus decompose the forces and moments acting. Another aspect related to the surface of the orthosis is the very comfort of wearing the orthosis by the end user. For this reason, a porous structure has been proposed on orthoses which have an increased area, the purpose of which is to reduce the discomfort when used by excessive sweating of the part of the foot which would come into direct contact with otherwise impermeable material and relieve the orthosis. The aim was to make the end user liked the orthosis and wanted to wear it daily. Plantar and dorsal flexion of the foot was an equally important factor in the design of orthoses. It is for this reason that a joint was designed on one of the orthoses, which was to allow the user to perform movements in the ankle area without limiting the increased effort or other complications. Another goal was to prevent arch disease. This proposal offers the possibility of further modifications of the shape and perforation according to the current state of health of the patient.

\section{Conclusions}

The aim of the work was to point out the advantages of the production of orthotic aids by additive technologies and the facilitation of the patient's life. If we compare the technology, which is most often used for the production of orthoses, with additive technologies, it can be stated that the positives of 3D printing predominate. 3D printing is less time consuming, more environmentally friendly (unused material can be used again, with SLS there is almost no waste material), more accurate and more cost-effective (both for the patient and the manufacturer). can be worn not only during sports but also during a normal day. Despite the fact that the orthosis looks elegant, rather as an accessory and not as a medical device, it does not lose its functionality. The advantage of this orthosis is the minimalist design and interesting design. Design software and an orthosis printer can be used to make design orthoses. In Slovakia, however, this technology is still used only minimally.

\section{Acknowledgments}

The article was created with the support of projects: VEGA 1/0316/18, VEGA: 1/0179/19, KEGA: 040TUKE-4/2019, KEGA: 041TUKE-4/2019.

\section{References and Notes}

[1] TELFER. S., PALLARI. J., MANGUIA. J., DALGARNO. K., McGEOUGH. M., WOODBURN. J. 2012. Embracing additive manufacture: implications for foot and ankle orthosis design. [online]. [cit. 30. Novembra 2019]. Dostupné z: https://bmcmusculoskeletdisord.biomedcentral.com/ articles/10.1186/1471-2474-13-84

[2] ŽIVČÁK. J, HUDÁK. R, BEDNARČíKOVA. L, TÓTH. T. 2012 Implantáty na mieru. Vydavatel'stvo: Strojnícka fakulta, Košice, 2012. ISBN 978-80-553-1396-2

[3] CHA. YH, LEE. KH, RYU. HJ, JOO. IW, SEO. A, KIM. DH, KIM. SJ.2017 Ankle-Foot Orthosis Made by 3D Printing Technique and Automated Design Software. [online]. [cit. 30. Novembra 2020]. Dostupné z: https://www.ncbi.nlm. nih.gov/pubmed/28827977

[4] WALBRAN. M, TURNER. K, McDAVID. A.J. 2016 Customized 3D printed ankle-foot orthosis with adaptable carbon fibre composites print joint. [online]. [cit. 30. Novembra 2020]. Dostupné z: https://www.tandfonline.com/doi/full/10.108 0/23311916.2016.1227022

[5] WATANABE.H, KUTSUNA.T, MORINAGA. H, OKABE.T. 1982 New plastic joints for plastic orthoses. [online]. [cit. 30. Novembra 2020]. Dostupné z: https://www.ncbi.nlm.nih. gov/pubmed/7079105

[6] 2019 Biomateriály a biotolerancie - Polymery v medicíne [7]. CERUL'A. L. Znalecký posudok pacienta

[8] CERUL’A. L'. Osobný archív pacienta

[9] Artec Eva. [online]. [cit. 23. Marca 2020]. Dostupnéz: https:// www.artec3d.com/portable-3d-scanners/artec-eva-v2

[10] Vývoj a výroba ortotických pomôcok aditívnymi technológiami. [online]. [cit. 23. Marca 2020]. Dostupné 
Acta Mechanica Slovaca

Journal published by Faculty of Mechanical Engineering - Technical University of Košice

z: $\quad$ http://www.strojar-inovator.sk/images/5.rocnik-2019/

Vyvoj-a-vyroba-ortetickych-pomocok-aditivnymitechnologiami.pdf

[11] ŽIVČÁK. J, HUDÁK. R, TKÁČOVA. M. 2010 Termovízna diagnostika. Prešov: Grafotlač s.r.o. Prešov, 2010. 200 ISBN 978-80-553-05333-2

[12] KyleMaxey, Artec3D Updateslts 3DScanning Studio. [online]. [cit. 23. Marca 2020]. Dostupné z: https://www.engineering. com/DesignSoftware/DesignSoftwareArticles/ ArticleID/12342/Artec-3D-Updates-Its-3D-ScanningStudio.aspx [13]. Vlastný zdroj - Meshmixer

[13] ČABA. M. 2015 Delenie 3D modelov pre 3D tlač . [online]. [cit. 23. Marca 2020]. Dostupné z: https://is.muni.cz/th/ cnp9d/bp.pdf 